\title{
Watering Eyes, CTCAE
}

National Cancer Institute

\section{Source}

National Cancer Institute. Watering Eyes, CT CAE. NCI Thesaurus. Code C143944.

A disorder characterized by excessive tearing in the eyes; it can be caused by

overproduction of tears or impaired drainage of the tear duct. 